\title{
PERENNIAL OR RUSSELL LUPIN: A POTENTIAL HIGH COUNTRY PASTURE LEGUME
}

\begin{abstract}
The origin of the horticultural strain of Lupinus polyphyllus is outlined and New Zealand investigations showing its potential as a pasture legume suited to moister, low fertility high country both in revegetation and as grazing are briefly reviewed. Provisional management guidelines on site selection, establishment, management, animal use and seed production are
\end{abstract} given.

Keywords: high country, Lupinus polyphyllus,soil fertility, Russell lupin

\section{INTRODUCTION}

Summer tourists travelling through South Island high country enjoy the multicoloured lupin flowering along roadsides. Farmers and farm advisers should also recognise this plant as a vigorous, persistent, perennial legume, well adapted to the high country environment.

Five years of agricultural trials at Lake Tekapo, Tara Hills and in Central Otago indicate that it has the potential to become a major grazing legume for moist, acid, loose-textured soil of the higher rainfall areas where only low to moderate fertiliser rates could be afforded. Other legumes are not suited to this combination of conditions. Perennial or Russell lupin's likely role is as standing feed for autumn or spring, or as a substitute tussock. Seasonal unacceptability limits its summer use.

This paper describes these attributes and gives provisional guidance on various aspects of its use.

\section{ORIGIN AND HISTORY}

There are several hundred different lupin species, mostly perennials originating from North and South America Some annual species, like the blue, white and yellow fodder or green-feed lupins, come from the Mediterranean region.

Lupinus polyphyllus, from which the horticultural Russell lupin was mostly derived, came originally from western North America (California and Washington). It was collected and introduced to Britain as a potential horticultural plant by Douglas in 1826. The species was originally predominantly blue-and-white flowered. The range of colours was widened this century by hybridisation with the tree lupin $(L$ arboreus) by George Russell. It was released commercially in the mid 1930s, and was probably brought into New Zealand gardens shortly after. The first major sowing in the high country was $8-10 \mathrm{~kg}$ of seed broadcast on to bare roadside soils about 1952 on the Sawdon Station section of the Tekapo/Burkes Pass road.

\section{USE IN REVEGETATION}

Until recently, most work with this lupin in New Zealand has been for revegetation (Nordmeyer \& Davis 1976; Nordmeyer et a/. 1978; Lambrechtsen 1986). The NZ Forest Service has shown that it can grow and persist well on high rainfall subsoils, with only low levels of applied phosphate. The phosphate in the large seeds also gives it a distinct advantage for establishment in low fertility soils. A 
comparison of several legumes on subsoils in the Craigieturn Range of North Canterbury showed white clover dominance in the second year after a single high application of superphosphate, sweet vernal (Anthoxanthum odoratom) and browntop (Agrostis capillaris) dominance by the fifth year, and then subsequent invasion and dominance by lupin.

The same trials showed that lupin and lotus (Lotus pedunculatus), unlike white clover (Trifolium repens), Caucasian clover (T. ambiguum), milk vetch (Astragalus cicer), and crown vetch (Coronilla varia), can tolerate high levels of soil aluminium which are prevalent in mid to higher rainfall areas of the high country. Russell lupin tends to accumulate aluminium in the foliage and thus shifts the aluminium concentration from the mineral soil to the surface organic matter. Lupin is also unusual in being able to accumulate manganese in the leaf tissue to high levels without detrimental effect (Davis 1961). This lupin is used in Europe for stabilisation of mine spoils and as a legume in young pine plantations.

\section{AGRICULTURAL PERFORMANCE}

The first major investigation of the potential of perennial lupin as a herbage legume was started in 1982 at the Grasslands Division trial site on Mt John Station, Lake Tekapo. Recently trials have been started at Tara Hills and by some farmers.

The Lake Tekapo site is in the mid rainfall zone $(600-650 \mathrm{~mm})$, has acid soil (pH 5.0-5.5) with Olsen $P$ of $10-20$ and $S$ of $1-2$, and at the start of the trials was hawkweed infested fescue tussock In two long-term trials on which most of this information is based, a mixture of 12 legumes and $\mathbf{1 2}$ grasses was sown and a range of managements imposed. In one trial 5 superphosphate rates $(0,50,100,250$ and $500 \mathrm{~kg} / \mathrm{ha} / \mathrm{yr}$ ), 3 stocking rates (moderate, high and low relative to the growth at each fertiliser level), and 2 stocking methods (mob or sustained) were used (Scott 8 Covacevich 1987). In a second trial 27 levels of $P$ and $S$ fertiliser rates from 0 to 100 kg element/ha.yr and mob stocking as required were used (Scott et al. 1989). Measurements over the subsequent 6 years have shown:

- Lupin was the most rapidly germinating species under cold spring conditions. - Lupin growth was similar to or better than that of alsike, red clover and white clover during the initial $1 \%$ year establishment phase.

- There was a strong fertiliser effect with lupin the dominant and highest yielding species at the lower fertiliser rates of $0-100 \mathrm{~kg} / \mathrm{ha} / \mathrm{yr}$ sulphur fortified superphosphate, and co-dominant with alsike clover at $250 \mathrm{~kg} / \mathrm{ha} / \mathrm{yr}$. White clover and alsike became dominant at the highest fertiliser level, with some grass becoming co-dominant in the later years.

- The grazing achieved generally depended on the fertiliser rates, but the greater growth of lupin at lower fertiliser levels gave greater grazing than would be expected from the fertiliser rate.

\section{LIVESTOCK ACCEPTABILITY}

Lupin is not particularly acceptable during summer. Young flower buds are often the first part eaten. All parts are taken in spring, but leaves are then grazed progressively less. All plant parts become acceptable again during autumn. It is less summer acceptable than alsike clover, another successful high country legume. This feature of lupin is undoubtedly due to alkaloids in the leaves.

Many species of lupin in other countries may be poisonous to stock at some stage, either directly because of their alkaloid content, or indirectly because of fungi living on the seed. To date, there is no indication that perennial lupin has any detrimental effects in New Zealand, but it has not extensively exposed to livestock 


\section{PROVISIONAL GUIDELINES}

\section{Place in farming systems}

Perennial or Russell lupin could be the main component of a mixture for standing maintenance feed for autumn and early winter, and as a component for early spring feed. Its large size would also provide shelter as a replacement for tussock.

Site

It is most suited to rocky, sandy or other loose-textured soils of low to moderate fertility, where with low competition it is likely to become the dominant species. This is a class of site for which there is no suitable pasture legume. Lupin does not do Well on fine-textured soils or clay. It does need moderate moisture, so suits mid to higher rainfall areas. Suitable sites may be areas with soils too thin and vegetation too open to justify full development. From its origin and present New Zealand distribution, riverbeds seem to be an ideal site, but to avoid the wrath of fishermen and conservationists it should not be sown there.

\section{Establishment}

Perennial or Russell lupin is the best establishing legume at the initial germination and cotyledon stage under cold and lower fertility conditions, but is very sensitive to competition thereafter until it reaches $10-15 \mathrm{~cm}$. Therefore the site should already have a high proportion of bare ground, or have been grubbed or otherwise partly cultivated, or a drill (e.g. rotary hoe type) should be used that creates considerable disturbance near the seed. Seeding rates should be $6-8 \mathrm{~kg} /$ ha, but because of the limited seed supply, rates as low as $2 \mathrm{~kg} / \mathrm{ha}$ are suggested. Like many high country oversowings, the inclusion of any grass in the initial mixture is not advised. Up to a quarter of the seed may be hard. It is probably better to retain this as insurance against initial failure rather than having the seed mechanically or acid scarified. Seed should be inoculant-coated for the speediest and best results. The recommended rhizobium strain is NZP 2141. Plants from uninoculated seed, as most of the present stands testify, do nodulate eventually.

Shallow spring drilling is probably best. Like all hill and high country sowings, stands should be ungrazed for the first $\mathrm{I}-2$ years, or at least until lupin reach a height of $30-40 \mathrm{~cm}$. The long-term vigour of any legume stand depends on good growth of root systems and nodules during the establishment period.

\section{Management}

Lax grazing is probably preferred, but the lupin can be periodically grazed to ground level and recover, with sufficient regrowth time. Plants flower from late November onwards. Seed shed will tend to thicken up stands which have open bare ground. This would be enhanced by reduced spring grazing. The lupin makes very pronounced growth in early spring, but the effect of grazing at that stage on subsequent performance is not known.

Late spring/early summer interaction of stocking pressure and lupin acceptability can be used to control stand density and bulk for other seasons. Under lower stocking rates in late spring/early summer, stock tend to select other species and allow lupin to increase. By contrast, heavy stocking in spring as well as in autumn/winter would reduce dense stands. The amount of late autumn/winter feed will depend on the summer/autumn regrowth period. Summer unacceptability of lupin may cause overgrazing of other undeveloped areas of a block during that period. Autumn frost tolerance is similar to that of alsike and red clover.

\section{Seed production}

It should be regarded as a special purpose crop on moisture retentive soils where agricultural machinery can be used. Sowing rates of about $7 \mathrm{~kg} / \mathrm{ha}$ at $30 \mathrm{~cm}$ row spacing and $16 \mathrm{~cm}$ within-row spacing should give yields of $500-2000 \mathrm{~kg} / \mathrm{ha}$. 
Flower production seems to be very sensitive to early spring competition and previous winter grass spraying and simazine treatment is probably required. Pod shattering makes seed collection difficult. At present, seed is obtained by handpicking: the whole stem is cut when a quarter or more of the pods are turning brown and dried further before threshing. Mechanical field harvesting will probably involve some early spring grazing or cutting to concentrate later flowering, a paraquat or diquat spray after flowering in late December to early January when a proportion of pods are brown, then direct heading in the morning damp 2-3 days later. Alternatively the crop could be cut and windrowed before picking it up with a header. Mechanical harvesting may be similar to or more difficult than for lotus.

\section{References}

Davis, M.R. 1981. Growth and nutrition of legumes on a high country yellow-brown earth subsoil. NZ journal of agricultural research 24: 321-48.

Lambrechtsen, N.C. 1986. Management and uses of Lupinus polyphyllus In Van Kraayenoord, C.w.S.; Hathaway, R.L. (Eds.). Plant Materials Handbook for Soil Conservation Vol. 2; Introduced plants.

Nordmeyer, A.H.; Davis, MR. 1976. Legumes in high country development. Proceedings NZ Grassland Association 38: 119-25.

Nordmeyer, AH.; Lang, M.H.; Roberts, Q. 1978. Legume establishment. In: Revegetation in the rehabilitation of mountain lands. NZ Forest Service. Forest Research Institute Symposium No. 16: 9-10.

Scott, D.; Robertson, J.G.; Burgess, R. 1989. Species and fertiliser efficiency a high country example. Proceedings NZ Grassland Association 50: (in press).

Scott, D.; Covacevich, N. 1987. Effect of fertiliser and grazing on a pasture species mixture in high country. Proceedings NZ Grassland Association 48: 93-98.

Scott, D.; Keoghan, J.; Cossens, G.; Maunsell, L.A; Floate, M.; Wills, B.; Douglas, G. 1985. Limitations to pasture production and choice of species. In Burgess, R.E.; Brock, J.L. (Eds.). Using herbage cultivars, Grasslands Research and Practice Series No. 3 NZ Grassland Association. 